\title{
Alberta to seek recovery of health costs associated with criminal activity
}

$\mathrm{T}$ he province of Alberta is poised to become the first jurisdiction in the world that will try to make crime pay — literally — by suing convicted people for the cost of treating injuries they sustain committing a crime.

Anyone from a participant who gets shot in a gang war to a conveniencestore robber or an illegal-drug user could be sued upon conviction for whatever it costs to patch them up (including ambulance fees, drugs and future treatments), plus interest backdated to the time of conviction.

Bill 48, the Crown's Right of Recovery Act, however, is attracting ridicule from legal and political experts, who are calling it misguided, unenforceable and even "a stake in the heart of medicare."

Chances are slim that the government will be able to collect money from down-and-out criminals, says Brian Hurley, president of Alberta's Criminal Trial Lawyers' Association, who calls the bill "pure political pandering" to the Conservative government's fundamentalist Christian supporters. "We like to top Texas every once in a while with right-wing stupidity - and you can quote me on that."

Alberta already has the power (under the Hospitals Act) to pursue drunk drivers and other "wrongdoers" for the cost of treating their victims. But Bill 48 expands that power to include the cost of treating the injuries the criminals inflict on themselves. However, if drunk drivers have liability insurance, their health care costs would be paid out of a fund created from mandatory contributions by the insurance industry.

With the bill's introduction on May 11, Alberta also joined 7 other provinces - British Columbia, New Brunswick, Ontario, Newfoundland and Labrador, Nova Scotia, Saskatchewan and Manitoba - that have introduced or passed health-cost recovery laws

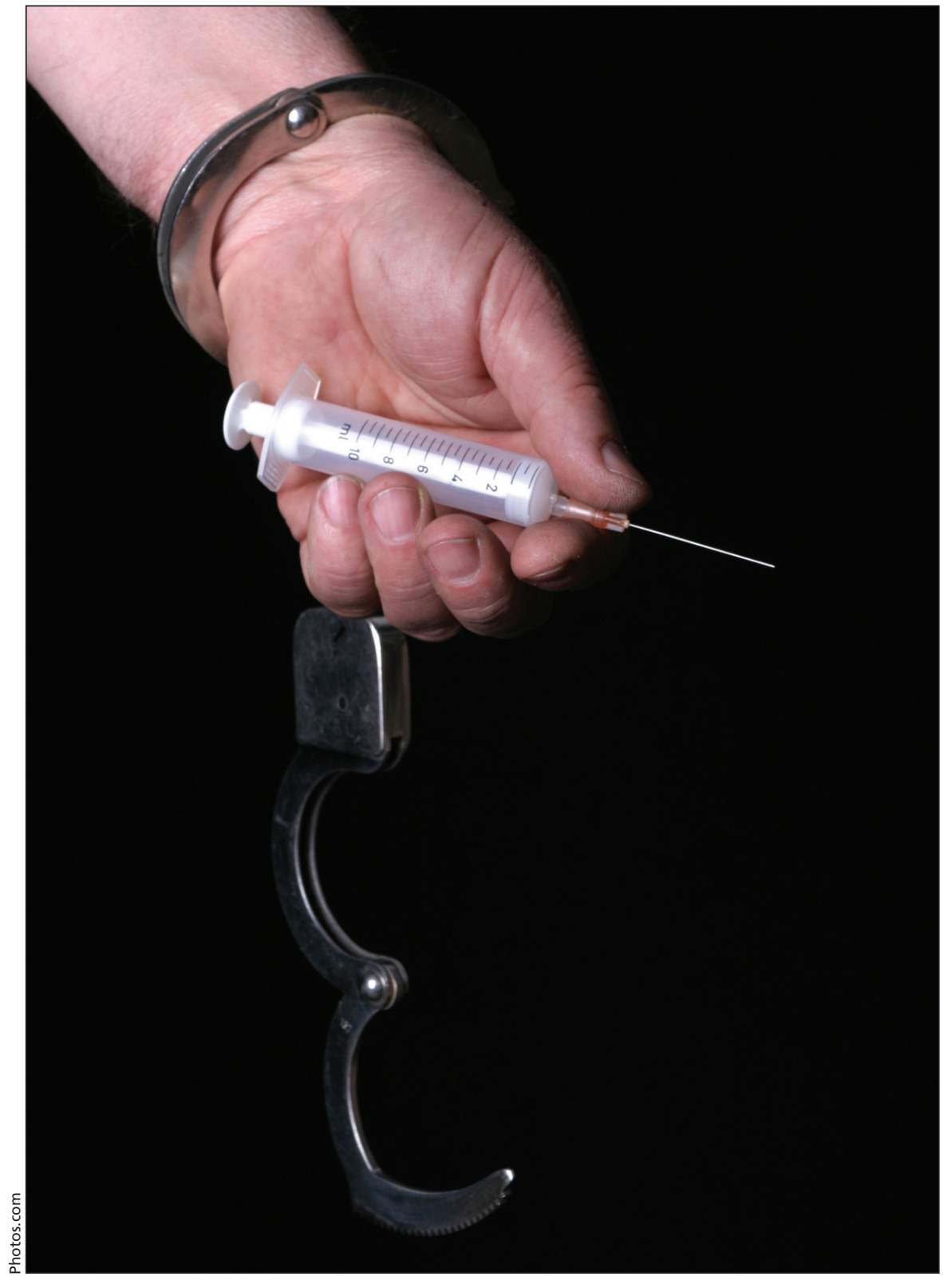

Critics say that the bureaucratic costs will outweigh cost-recovery under Alberta's new legislation to make criminals pay for medical treatment.

allowing them to sue big tobacco to recoup the massive costs of health care treatment for tobacco-related diseases.

The government is selling the legislation as a crackdown on crime and a costsavings for taxpayers. Taxpayers "should not be responsible for health costs caused by the wrongful acts or omissions of others," Health and Wellness Minister Ron Liepert told reporters. Bill 48 "will help us recover those costs, which will benefit Albertans." 
But observers say the bill will do nothing to deter criminal activity and could wind up costing taxpayers money. Most criminals come from disadvantaged socio-economic groups and couldn't pay for their ambulance rides, Hurley says. "If you're at the level where you rob a convenience store for $\$ 70$ or a hundred bucks to buy drugs, you have no money. ... We would spend far more money on the government bureaucracy trying to collect from these people than the funds we would recover from them."

"I don't think sending bills to criminals in the mail is going to get many results," says John Church, associate professor of political science at the University of Alberta in Edmonton, Alberta. Church wonders if the government should instead dip into the proceeds of major crimes - including major assets such as houses and cars seized by the Crown under the Victims Restitution and Compensation Payment Amendment Act.

But the government says that's not how the money will be recovered.
Instead, says Howard May, a spokesman for Alberta Health and Wellness, the government will go after individuals. An injured person's progress will be tracked through the courts, and if he or she is convicted of a Criminal Code offence, health ministry staff and lawyers from government or private practice will decide whether to pursue the claim and recoup the health costs through a settlement or a lawsuit. If the criminal is ordered to pay, the government would decide whether to pursue collection.

It's "too early to tell" what this will cost the taxpayer, May says. The government doesn't expect many such cases in the first place, so it doesn't anticipate significant extra work. May also says the Crown probably won't pursue a claim unless it believes it is likely to collect.

Opposition parties and medical ethicists have charged that Bill 48 may violate the Canada Health Act, by forcing people to pay for medically necessary treatment. The government disagrees and argues that it's confident the legis- lation would withstand a legal challenge, because no one is being denied medical treatment; they are just being asked to pay for it later.

That stance has prompted even conservative observers to wonder if Bill 48 is the slippery slope that could lead the Tories to start billing anyone who engages in risky behaviour or bad health habits, such as smoking, drinking, back-country skiing, cycling without a helmet and being overweight.

The Alberta Medical Association has taken no position on the controversial provisions of the bill. The association is grateful for any additional dollars for health care, says Assistant Executive-Director Ron Kustra, and beyond that, is satisfied that Bill 48 would not affect the way doctors practise. The bill passed first reading before the Legislature recessed for the summer. It will likely be passed into law when Members of the Legislative Assembly resume sitting in the fall. Christie McLaren, Canmore, Alta.

DOI:10.1503/cmaj.091125 